DOI: https:// doi.org/10.21564/2707-7039.2.242928

УАК 340.1

\title{
Борис Гумько*
}

\section{КОНСТИТУЦІЙНІ ЦІННОСТІ ТА НОВА ФІЛОСОФІЯ СУДОВОЇ ВЛАДИ В УКРАЇНІ: ЛЮДИНА, ВЕРХОВЕНСТВО ПРАВА, ГІДНІСТЬ}

$\Pi$

ропонуємо Ао Вашої уваги Аруге видання монографії, яка розкриває філософські та судові аспекти конституційних цінностей. ${ }^{1}$ У АосліАженні розкривається концепція конституції як живого інструменту, сутність якої відображають основні конституційні цінності. Автором застосований природно-правовий піАхіА, який Аозволив запропонувати концепцію конституції, змістовне наповнення якої активно розвивається разом із розвитком суспільства, що Аозволило автору виділити і запропонувати ієрархічну систему конституційних цінностей, на вершині якої заходиться АюАська гіАність.

У монографії всебічно проаналізовано окреслену проблематику віА перших спроб їх філософського осмислення періоду Античності і до нашого часу. Особливо підкреслено значення впливу християнської релігії на місце і роль конституційних цінностей, а головне - на роль і значення мюдини у суспільстві, яка поступово переходить у стан вищої цінності як творіння Божого. Епоха Нового часу, безумовно, була етапом філософського і ментального прориву, коли рівність, свобода, братерство та справеАливість чи не вперше отримали об’єктивацію в позитивному праві. Значна увага автора зосереАжена на німецькій класичній філософії, коли Кантом, Гегелем та іншими тогочасними мислитемями були запропоновані доктринальні аспекти свободи, рівності, справеАливості, прав мюАини та АюАської гіАності.

Історичний розвиток системи конституційних цінностей зазнав і трагічних поворотів, оАним із яких стала Аруга світова війна, яка була найбільшою за мюАськими втратами і заподіяними нею стражАаннями. Проте впевненою віАповіААю цивікізованого АюАства на ці дії стало об’єАнання навколо спільних цінностей і насампереА навколо мюАської

\footnotetext{
* Гулько Борис Іванович, Голова Касаційного цивільного суду в скиаді Верховного Суду, Заслужений юрист України.

Borys Gulko, Chairman of the Civil Court of Cassation of the Supreme Court, Honored Lawyer of Ukraine.

${ }^{1}$ Оксана Грищук, Конституційні цінності: філософські та судові аспекти. Монографія. Видання 2-ге доопрацьоване і доповнене (Київ: Ваіте, 2020).
} 
гідності. НеАаремно очільники фашистської Німеччини, які на Нюрнбергському трибуналі заявили, що вони не порушували чинного позитивного права, все ж були притягнуті світовою спільнотою Ао віАповідальності за зАочини проти мюАяності. Саме

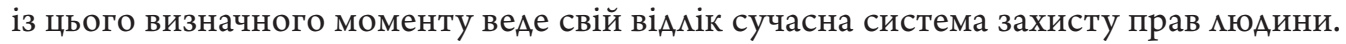
Саме ця методологічна основа дозволила створити такі міжнародні організації, як ООН, РаАа Європи, Європейський Союз. Саме керуючись природно-правовою методологією, Загальна декларація прав мюАини, а пізніше Міжнародний пакт про економічні, соціальні і кумьтурні права та Міжнародний пакт про громаАянські і політичні права, прийняті ООН, визнали мюАську гіАність Ажерелом основних прав і свобод АюАини. Такий піАхіА АОзволив у межах РаАи Європи прийняти Європейську конвенцію і створити Європейський суА з прав АюАини, який $є$ ефективним інструментом захисту прав і свобод мюАини, зокрема і в Україні, і саме такий піАхіА Аозволив піАтвердити у преамбулі Конституції України європейську іАентичність Українського народу і незворотність європейського курсу України.

Аругий великий блок питань, які розглянуто у монографії, - це судові аспекти конституційних цінностей. Автор зібрама і проаналізувака практику конституційних судів Федеративної Республіки Німеччина та Помьщі, а також практику Конституційного Суду України щодо розуміння ними конституційних цінностей. Проведений аналіз розкриває цікаві приклаАні аспекти тлумачення змісту конституційних цінностей конституційними судами при розгляді ними конкретних справ. Цікавим показовим, як на мене, є рішення Конституційного Суду України віА 23 травня 2018 р. 5-p/2018, де він, керуючись найсучаснішими надбаннями філософії права і цінностями та принципами міжнародного права, вказав, що мюАську гіАність необхіАно трактувати як право, гарантоване ст. 28 Конституції України, і як конституційну цінність, яка наповнює сенсом мюАське буття, $€$ фундаментом Аля всіх інших конституційних прав, мірилом визначення їх сутності та критерієм допустимості можливих обмежень таких прав. Цим рішенням було піАкреслено місце і роль конституційних цінностей та значення

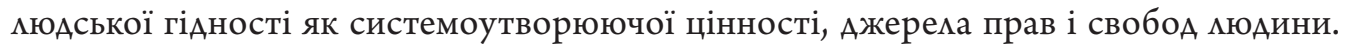

Авторкою піАкреслено, що конституційні цінності є ефективним інструментом, регулятором суспільних віАносин. Якщо Аержавою створені умови Аля реалізації мюАської гіАності, свободи, справеАливості, рівності, Аемократії, то в такій Аержаві виникає і діє стан верховенство права. Автор аргументовано обстоює позицію, що верховенство право $\epsilon$ інструментальною (процеАурною) цінністю, яка виникає за умови ефективної реалізації вищеназваних основних конституційних цінностей. Верховенство права розглядається як своєріАний тест, який відображає, наскільки ефективно реалізуються основні конституційні цінності.

Запропонований піАхіА узгоАжується з правовою позицією Конституційного Суду України, який у своєму рішенні віА 2 мистопаАа 2004 р. № 1-33/2004 вказав, що верховенство права розгляаається як панування права в суспільстві, а тому вимагає віА Аержави його втілення у правотворчу та правозастосовну Аіяльність, зокрема 
в закони, які за своїм змістом мають бути проникнуті передусім іАеями соціальної справеАливості, свободи, рівності тощо. ОАним із проявів верховенства права $є$ те, що право не обмежується мише законодавством як однією з його форм, а включає й інші соціальні регулятори, зокрема норми моралі, традиції, звичаї тощо, які мегітимовані суспільством і зумовлені історично досягнутим культурним рівнем суспільства. Всі ці елементи права об’єАнуються якістю, що віАповіАає іАеології справеАливості, іАеї права, яка значною мірою Аістала відображення в Конституції України.

Запропонований авторкою піАхіА узгоджується також із баченням Венеційської комісії, яка вказала, що іАея верховенства права переАбачає систему чітких та переАбачуваних приписів права, віАповіАно Ао яких кожному належить право на ставцення Ао нього з боку всіх суб'єктів ухвалення рішень на основі гіАності, рівності й розумності та віАповіАно Ао приписів права, а також право на можливість звернутися з оскарженням рішень Ао незалежних і безсторонніх суАів у рамках справеАливих судових процеАур. Венеційська комісія у своїй доповіАі Аійшла висновку, що, попри розбіжності в поглядах, існує консенсус стосовно обов'язкових елементів поняття «верховенство права», зокрема: законність, включаючи прозорий, піАзвітний і демократичний процес ввеАення в Аію приписів права; юриАична визначеність; заборона свавілця; Аоступ Ао правосуААя, преАставленого незалежними та безсторонніми суАами, вкАючно з тими, що зАійснюють суАовий нагляА за аАміністративною Аіяльністю; Аотримання прав мюАини; заборона Аискримінації та рівність переА законом.

Таким чином, виАається піАставним, що принцип верховенства права має ціннісну природу, у його основі межить іАея обмеження сили правом і запобігання свавілюю. Саме верховенство права обмежує суверенну волю держави, коли Аержава порушує

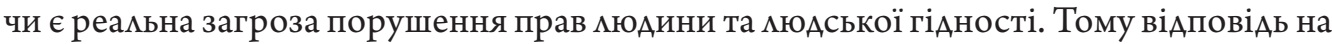
питання про межу суверенної волі держави і межу застосування сили потрібно шукати в кожному конкретному випаАку через баланс основоположних конституційних цінностей, в першу чергу через призму поваги Ао мюАської гіАності.

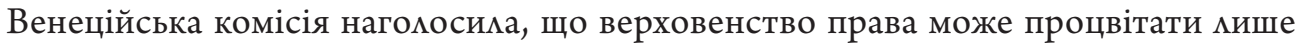
в країні, жителі якої мають почуття колективної віАповіАальності за його впроваАження, робцячи його невіААільною частиною власної правничої, політичної та соціацьної культури. Як віАомо, у найширшому розумінні соціальна культура розглялається як система загальновизнаних соціальних цінностей. Розвинена соціальна культура передбачає віАповіАність індивіАуальних цінностей і стандартів повеАінки АюАини і соціальних цінностей. Такий взаємозв'язок $є$ вирішамьним при кегітимації Аержавної вмаАи, а мегітимність як частина правосвідомості являє собою переконаність у законності вмади, тобто у їі праві приймати загальнообов' язкові рішення. Таким чином,

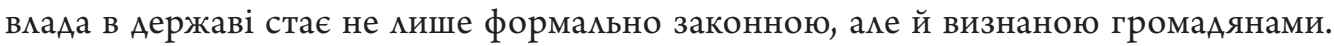
Особливого значення це набуває у сфері судової влаАи, де спільно сформовані конституційні цінності $є$ ефективним інструментом збільшення Аовіри Ао судової вцаАи та піАвищення авторитету суду. 
Видається, що запропоновані професоркою Оксаною Грищук іАеї є цікавими, новаторськими, науково обгрунтованими. Особливо наголошу, що кожна теорія, Аоктрина потребує перевірки практикою, а тому пропоную монографію «Конституційні цінності: філософські та судові аспекти» Ао прочитання, перш за все, своїм колегам - суААям, які у свойй роботі кожного Аня стикаються з питаннями застосування права, а це завжАи питання балансування цінностей. Сподіваюсь, що монографія стане корисною при вирішенні складних практичних питань застосування і тлумачення права.

(C) Б. Гулько, 2020

Борис Гуфько. Конституційні цінності та нова філософія судової вмади в Украӥні: мюдина, верховенство права, гідність

Анотація. Рецензія на монографію О. В. Грищук «Конституційні цінності: філософські та судові аспекти» (Грищук, Оксана. Конституційні цінності: філософські та судові аспекти. Монографія. Видання 2-ге доопрацьоване і доповнене. Київ: Ваіте, 2020).

Борис Гумько. Конституционные ценности и новая фимософия суАебной вмасти в Украине: человек, верховенство права, достоинство

Аннотация. Рецензия на монографию О. В. Грищук Конституционные ценности: фимософские и судебные аспекты» (Грищук, Оксана. Конституційні иінності: філософські mа судові аспекти. Монографія. Видання 2-е доопрацьоване і доповнене. Київ: Ваіте, 2020).

Boris Gulko. Constitutional Values and a New Philosophy of the Judiciary in Ukraine: Human, Rule of Law, Dignity

Abstract. Review of O. V. Gryshchuk's monograph “Constitutional Values: Philosophical and Judicial Aspects” (Hryshchuk, Oksana. Constitutional Values: Philosophical and Judicial Aspects. Monograph. 2nd edition revised and supplemented. Kyiv: Vaite, 2020).

ОАержано/Received 10.12.2020 